\title{
Influence of Soybean Seeding Rate, Row Spacing, and Herbicide Programs on the Control of Resistant Waterhemp in Glufosinate-Resistant Soybean
}

\author{
John L. Schultz, D. Brenton Myers, and Kevin W. Bradley*
}

Field experiments were conducted in 2012 and 2013 to determine the effects of row spacing, seeding rate, and herbicide programs on multiple-resistant waterhemp control and yield in glufosinateresistant soybean. The two herbicide programs evaluated were: (1) a PRE application of fomesafen plus $S$-metolachlor followed by early POST application of glufosinate plus acetochlor, referred to as the PRE followed by (fb) POST with residual (w/RES) herbicide program; and (2) an early POST followed by a late POST application of glufosinate, referred to as the two-pass POST herbicide program. Results indicate that the PRE fb POST w/RES program provides greater control of resistant waterhemp compared to the two-pass POST herbicide program. In 2012, the PRE fb POST w/RES program resulted in a 99\% waterhemp density reduction and $156 \mathrm{~kg} \mathrm{ha}^{-1}$ increase in yield compared to the $72 \%$ density reduction by the two-pass POST program. In 2013, the two-pass POST program was equally as effective on density reduction and yield as the PRE $\mathrm{fb}$ POST w/RES program. Waterhemp control and density reduction was always greatest with 19- and 38-compared to 76-cm rows. In 2012, the PRE fb POST w/RES program provided at least $95 \%$ control and greater than 98\% density reduction across all row spacings, whereas the two-pass POST program provided 95\%, $95 \%$, and $85 \%$ control and $87 \%, 80 \%$, and $50 \%$ density reduction in 19-, 38-, and 76-cm rows, respectively. Soybean seeding rate did not affect waterhemp control or density in either year. In both years, 165,000 seeds $\mathrm{ha}^{-1}$ yielded lower than the three higher seeding rates. Overall, results from these experiments indicates that the use of a PRE $\mathrm{fb}$ POST w/RES program, narrow-row spacing, and seeding rates of 240,000 to 315,000 seeds $\mathrm{ha}^{-1}$ or greater provides the greatest waterhemp control, density reduction, and soybean yield when multiple resistant waterhemp is present.

Nomenclature: Common waterhemp, Amaranthus rudis Sauer; soybean, Glycine max (L.) Merr. Key words: Pigweed, soybean row spacing, weed control.

\begin{abstract}
En 2012 y 2013, se realizaron experimentos de campo para determinar los efectos de la distancia entre hileras, la densidad de siembra, y los programas de herbicidas sobre el control de Amaranthus rudis resistente a múltiples herbicidas y sobre el rendimiento de soja resistente a glufosinate. Los dos programas de herbicidas evaluados fueron: (1) una aplicación PRE de fomesafen más $S$-metolachlor seguida de una aplicación POST temprana de glufosinate más acetochlor, el cual se designó como el programa de PRE seguido de (fb) POST con herbicida residual (w/RES); y (2) una aplicación POST temprana seguida por una aplicación POST tardía de glufosinate, el cual fue designado como el programa de dos pases con herbicida POST. Los resultados indican que el programa PRE fb POST w/RES brinda mayor control de $A$. rudis resistente que el programa con dos pases con herbicida POST. En 2012, el programa PRE fb POST w/RES resultó en una reducción de $99 \%$ de la densidad de $A$. rudis y $156 \mathrm{~kg} \mathrm{ha}^{-1}$ de incremento en el rendimiento en comparación con una reducción de la densidad de $72 \%$ con el programa de dos pases POST. En 2013, el programa de dos pases POST fue igualmente efectivo con respecto a la reducción en la densidad de la maleza y el rendimiento del cultivo que el programa PRE fb POST w/RES. El control de $A$. rudis y la reducción en la densidad de sus poblaciones fueron siempre mayores en hileras espaciadas a 19 y 28 que a $76 \mathrm{~cm}$. En el 2012, el programa PRE fb POST w/RES brindó al menos $95 \%$ de control y una reducción en la densidad superior a $98 \%$ en todas las distancias entre hileras, mientras que el programa de dos pases POST brindó 95\%, $95 \%$, y $85 \%$ de control y $87 \%, 80 \%$, y $50 \%$ de reducción en la densidad en hileras espaciadas a 19, 38, y $76 \mathrm{~cm}$, respectivamente. La densidad de siembra de la soja no afectó el control de $A$. rudis o su densidad en ningún año. En ambos años, 165,000 semillas $\mathrm{ha}^{-1}$ tuvo un menor rendimiento que las tres densidades de siembra más altas. En general, los resultados de estos experimentos indican que el uso de un programa PRE fb POST w/RES, distancia entre hileras menores, y densidades de siembra de 240,000 a 315,000 semillas ha $^{-9}$ o mayores brindan el mayor control de $A$. rudis, la mayor reducción en sus poblaciones, y el mayor rendimiento de la soja cuando $A$. rudis con resistencia múltiple está presente.
\end{abstract}

DOI: 10.1614/WT-D-14-00071.1

* Graduate Research Associate, Assistant Professor, and Associate Professor, Division of Plant Sciences, 201 Waters Hall, University of Missouri, Columbia, MO 65211. Corresponding author's E-mail: BradleyKe@missouri.edu
The adoption of glyphosate-resistant (GR) soybean and conservation practices over the last several decades has resulted in an increased reliance on herbicides as one of the primary methods of weed 
control (Culpepper et al. 2000; Krausz et al. 1993; Young 2006). As production was simplified with GR soybean, many producers relied on glyphosate as their primary and often sole method of weed control (Powles 2008; Young 2006). The continuous use of glyphosate over multiple years has led to increased selection pressure for weeds to evolve resistance to glyphosate (Powles 2008; Young 2006). The evolution of glyphosate resistance in weeds such as waterhemp has complicated weed management and increased production costs in corn (Zea mays L.), cotton (Gossypium hirsutum L.), and soybean production systems dramatically.

Currently, waterhemp is the most common and troublesome weed found in Missouri, Iowa, and Illinois (Bradley et al. 2007; Hager et al. 2000; Legleiter and Bradley 2008; Rosenbaum and Bradley 2013; Waggoner and Bradley 2011). In recent years, the number of waterhemp populations with resistance to multiple herbicide mechanisms of action has risen in Missouri and throughout the Midwest. Waterhemp in Missouri, Iowa, and Illinois has evolved resistance to 5-enolpryuvylshikimate-3phosphate synthase (EPSPS)-, protoporphyrinogen oxidase (PPO)-, 4-hydroxyphenylpyruvate dioxygenase (HPPD)-, photosystem II-, and acetolactate synthase (ALS)-inhibiting herbicides, with one population in Missouri being resistant to all five modes of action (Heap 2014; Schultz et al. 2014). Kansas has documented waterhemp with resistance to EPSPS-, PPO-, photosystem II-, and ALSinhibitors, and Nebraska has documented waterhemp with resistance to synthetic auxins, EPSPS-, HPPD-, and photosystem II-inhibiting herbicides (Bernards et al. 2012; Heap 2014; Shoup et al. 2003).

The evolution of waterhemp or other weeds with resistance to multiple sites of action will require producers to diversify their production systems and integrate optimum cultural and herbicidal control methods (Bradley 2013; Heap 2014; Norsworthy et al. 2012; Schultz et al. 2015). Cultural practices, such as row spacing and seeding rate, can significantly impact weed control (Anderson 1996; Grichar et al. 2004; O'Donovan et al. 2001). The majority of research studies conducted to date have shown that soybean planted in narrow rows can contribute to greater season-long weed control than wide-row soybean (Bradley 2006; Buehring et al. 2002; Burnside 1979; Burnside and Colville 1964;
Dalley et al. 2004; Legere and Schreiber 1989; Nelson and Renner 1998; Puricelli et al. 2003; Rich and Renner 2007; Steckel and Sprague 2004; Yelverton and Coble 1991). Harder et al. (2007) observed lower weed density and biomass following an effective POST herbicide application in 19compared to $76-\mathrm{cm}$ rows. Buehring et al. (2002) found that sicklepod [Senna obtusifolia (L.) H. S. Irwin and Barneby] control was 29\% higher in 19compared to 76-cm row soybean. Steckel and Sprague (2004) reported a 57\% waterhemp biomass reduction in 19- compared to $76-\mathrm{cm}$ row soybean when waterhemp emergence occurred at the V2 to V3 soybean growth stage. Early soybean canopy development in 19- to $38-\mathrm{cm}$ row soybean also exceeds that of $76-\mathrm{cm}$ row soybean, resulting in lower radiation transmitted through the canopy, and partially accounts for the greater competitiveness of narrow- vs. wide-row soybean (Puricelli et al. 2003; Steckel and Sprague 2004). As row spacing increases, weed resurgence escalates due to the amount of light penetrating to the soil surface (Steckel and Sprague 2004; Yelverton and Coble 1991). As a result, soybean planted in $76-\mathrm{cm}$ rows or greater requires earlier and more extended weed management programs to prevent yield loss than soybean planted in narrower rows (Knezevic et al. 2003; Mulugeta and Boerboom 2000).

Soybean plant population is another cultural practice that can be manipulated for optimum weed management. Buehring et al. (2002) found that a soybean population of 688,000 plants $\mathrm{ha}^{-1}$ resulted in $92 \%$ control of sicklepod compared to only $29 \%$ control with a soybean population of 269,000 plants ha ${ }^{-1}$. Norsworthy and Oliver (2002) observed greater hemp sesbania [Sesbania exaltata (Raf.) Rydb. ex A. W. Hill] biomass reduction with soybean populations of 521,000 plants ha ${ }^{-1}$ compared to 217,000 and 371,000 plants $\mathrm{ha}^{-1}$. Harder et al. (2007) found that weed biomass was not suppressed by soybean populations of 124,000 to 198,000 plants ha $^{-1}$ across $19-, 38-$, and 76-cm rows, but was suppressed by soybean populations of 300,000 to 445,000 plants ha ${ }^{-1}$. At 300,000 plants $\mathrm{ha}^{-1}$, the biomass reduction was greater in $19-\mathrm{cm}$ rows than 38- and 76-cm rows. Although soybean populations greater than 450,000 plants $\mathrm{ha}^{-1}$ can provide higher weed control, the seed cost associated with these seeding rates often exceeds the benefit (Norsworthy and Oliver 2001). 
Table 1. Dates of major field operations and waterhemp size at the time of the herbicide applications.

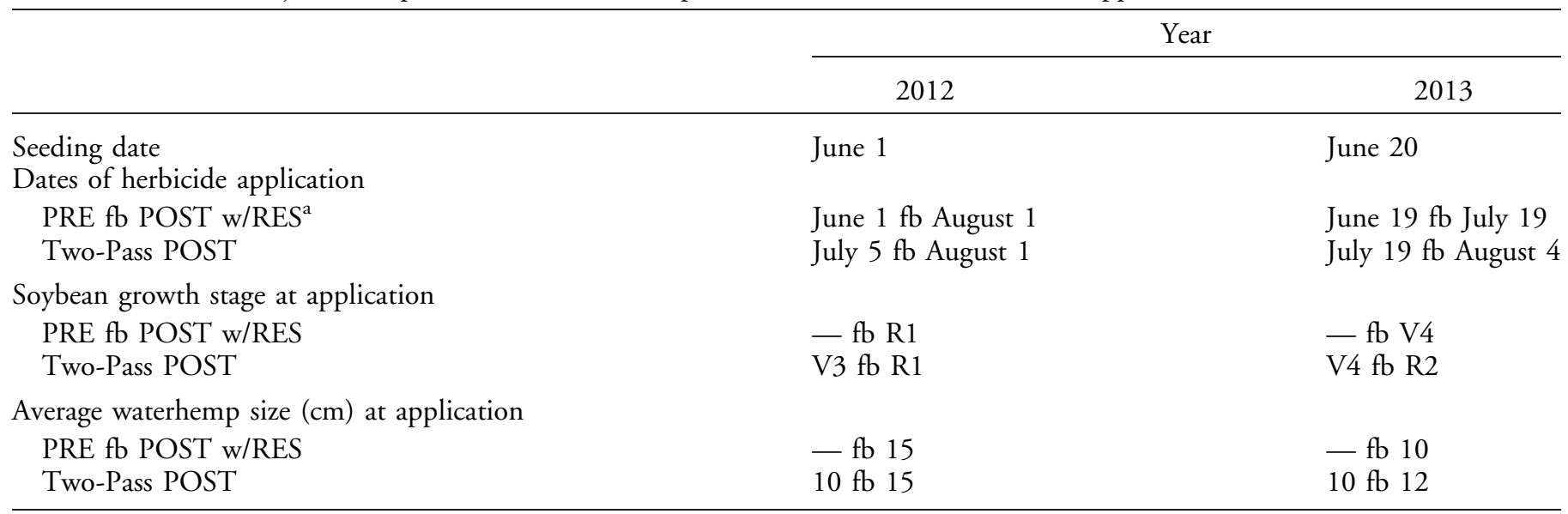

a Abbreviations: fb, followed by; w/RES, with residual.

The simplicity of the GR cropping system led many producers to rely solely on POST herbicide applications for weed control in soybean (Powles 2008; Young 2006). Waterhemp has evolved resistance to many of the current POST herbicide options used in GR soybean; however, glufosinate remains an effective POST herbicide for the control of this species, as long as applications are made to plants less than $15 \mathrm{~cm}$ in height. Producers can utilize glufosinate applications in-crop if they plant glufosinate-resistant soybean. Craigmyle et al. (2013) observed up to $90 \%$ waterhemp control with one POST glufosinate application in glufosinate-resistant soybean. However, POST-only herbicide applications can result in herbicide failures and the evolution of herbicide resistance in weed biotypes (Bradley 2013; Powles 2008). The addition of PRE and POST residual herbicide applications has been proven to reduce weed density, improve season-long weed control, and reduce the opportunity for the evolution of herbicide resistance (Bradley 2013; Craigmyle et al. 2013; Legleiter et al. 2009; Spaunhorst et al. 2014). The use of herbicides that act at multiple sites of action in both PRE and POST applications is critical to the management of multiple-resistant waterhemp (Bradley 2013).

The influence of row spacing, seeding rate, and herbicide program on the management of GR waterhemp in glufosinate-resistant soybean has not been researched extensively. The objectives of this research were to determine the effect of row spacing, seeding rate, and herbicide programs on multiple- resistant waterhemp control and yield in glufosinate-resistant soybean.

\section{Materials and Methods}

Site Description. An experiment was conducted in 2012 and repeated in 2013 at a field site in Randolph County, Missouri (39.3058 ${ }^{\circ} \mathrm{N}$, $\left.-92.3736^{\circ} \mathrm{W}\right)$ that contained a dense infestation of waterhemp that exhibited resistance to glyphosate, ALS-, and PPO- inhibiting herbicides. This site has been in continuous soybean production for at least $10 \mathrm{yr}$ and is an upland area with a clay pan soil. The soil type at this location was a Putnam silt loam (Fine, smetitic, mesic Vertic Albaqualfs) with an average of $2.1 \%$ organic matter and $\mathrm{pH}$ of 6.3 in both years. Truman 938 LL soybean containing a glufosinate-resistance trait (maturity group 3.8, Merschman Seeds, West Point, IA) was seeded at $165,000,240,000,315,000$, and 390,000 seeds $\mathrm{ha}^{-1}$ in rows spaced 19,38 , and $76 \mathrm{~cm}$ apart into a conventional-tilled seedbed. Tillage consisted of two passes with a field cultivator. Soybean were planted in 38 - and $76-\mathrm{cm}$ rows using a variable rate planter (Almaco ${ }^{\circledR}$, Nevada, IA) and in 19-cm rows using a variable rate grain drill (Wintersteiger ${ }^{\circledR}$, Salt Lake City, UT). Dates of major field operations for each experiment are provided in Table 1. Monthly rainfall totals and average monthly temperatures are presented in Table 2 .

The experimental design was a randomized complete block in a split-plot arrangement of treatments. Whole plots consisted of herbicide programs, and subplots were seeding rates. The 
Table 2. Monthly rainfall ( $\mathrm{mm}$ ) and average monthly temperatures (C) in comparison to the 30-yr averages from April through October in 2012 and 2013 at the Randolph County, Missouri research location.

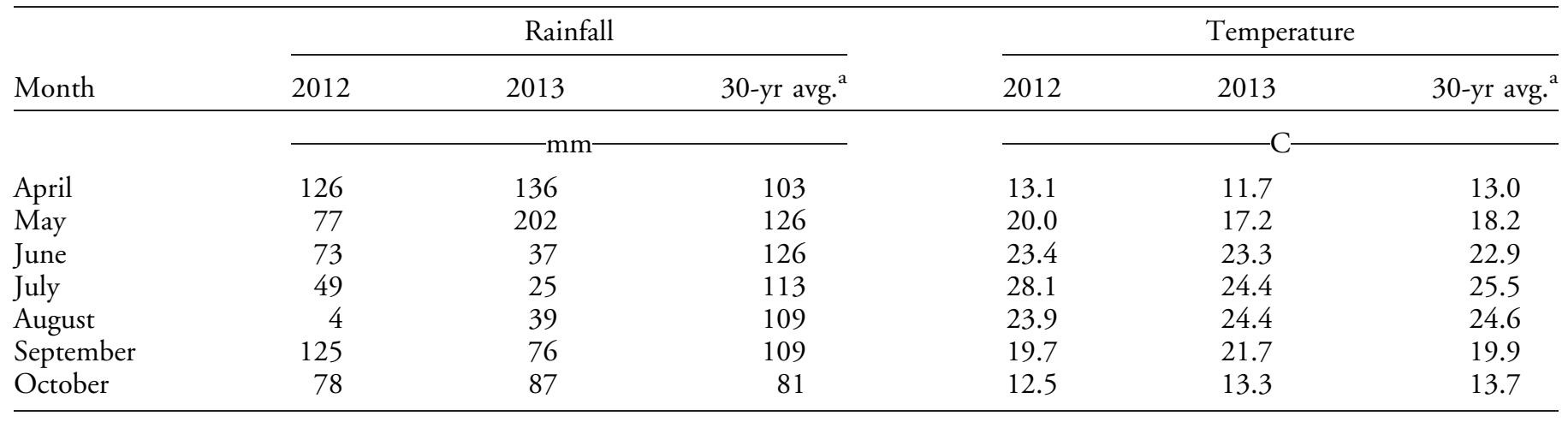

a 30-yr averages (1982-2011) obtained from National Climatic Data Center (2014).

experiment was conducted with six replications in 2012 and four replications in 2013. Individual plots measured 3 by $9 \mathrm{~m}$ in size. Two herbicide programs were evaluated: (1) a PRE application of fomesafen plus $S$-metolachlor $\left(0.27+1.12 \mathrm{~kg}\right.$ ai ha $\left.{ }^{-1}\right)$ followed by an early POST application of glufosinate plus acetochlor $\left(0.60 \mathrm{~kg} \mathrm{ai}+1.26 \mathrm{~kg} \mathrm{ai} \mathrm{ha}^{-1}\right)$, referred to as the PRE fb POST w/RES herbicide program; and (2) an early POST application of glufosinate $\left(0.60 \mathrm{~kg} \mathrm{ha}^{-1}\right)$ followed by a late POST application of glufosinate $\left(0.60 \mathrm{~kg} \mathrm{ha}^{-1}\right)$, referred to as the two-pass POST herbicide program. The specific herbicide formulations utilized are listed in Table 3. All treatments were applied with a $\mathrm{CO}_{2}$ pressurized backpack sprayer equipped with XR8002 flat-fan nozzle tips (TeeJet ${ }^{\circledR}$, Spraying Systems Co., P.O. Box 7900, Wheaton, IL 60187) calibrated to deliver $140 \mathrm{~L} \mathrm{ha}^{-1}$ at $117 \mathrm{kPa}$. Treatments were applied at a speed of $5 \mathrm{~km} \mathrm{hr}^{-1}$. A nontreated control for each row spacing and seeding rate was included for comparison. PRE treatments were applied prior to planting. Early POST applications were made once weeds reached $10 \mathrm{~cm}$ in height. Late POST applications were made when weed regrowth reached $10 \mathrm{~cm}$ in height.
Treatment Evaluation and Data Collection. Visible weed control and crop injury evaluations were assessed at regular intervals after application on a scale of 0 to $100 \%$, where 0 represented no plant death or crop injury and 100 was equivalent to complete plant death. Late-season waterhemp density was determined at the $\mathrm{R} 4$ reproductive stage each year by counting individual plants within the center 1 by $9 \mathrm{~m}^{2}$ area of each plot. Soybean plant densities for each seeding rate were determined at the R4 reproductive stage each year by counting two random $1-\mathrm{m}$ subsamples of the 38and $76-\mathrm{cm}$ rows and two $0.5-\mathrm{m}^{2}$ areas within plots that were planted in 19-cm rows (Table 4). Soybean were harvested from the center 1.5 by $9 \mathrm{~m}^{2}$ within each plot with a small plot combine (Kincaid ${ }^{\circledR}$, Haven, KS) and yield was adjusted to $13 \%$ moisture content.

Statistical Analysis. Late-season visible waterhemp control, waterhemp density, and soybean yield data were analyzed using the PROC GLM procedure in SAS (SAS 9.3, SAS ${ }^{\circledR}$ Institute Inc. Cary, NC). Herbicide program, row spacing, and seeding rate were considered fixed effects in the model. Significant interactions were present between years;

Table 3. Source of materials used in the experiments.

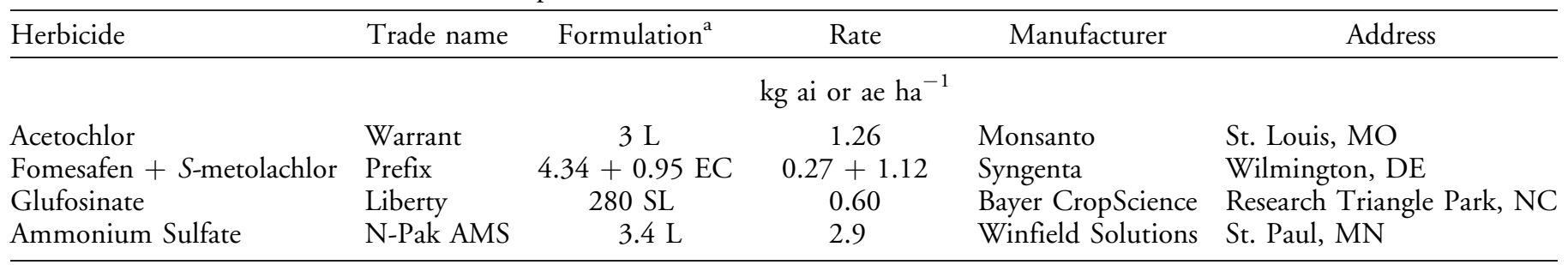

a Abbreviations: L, liquid; EC, emulsifiable concentrate; SL, soluble liquid. 
Table 4. Influence of soybean seeding rate on final soybean density.

\begin{tabular}{llc}
\hline & \multicolumn{2}{c}{ Soybean plant density $^{\mathrm{a}-\mathrm{c}}$} \\
\cline { 2 - 3 } Seeding rate & \multicolumn{1}{c}{2012} & \multicolumn{2}{c}{2013} \\
\hline Seed ha & \multicolumn{2}{c}{ plants ha $^{-1}$} \\
165,000 & $139,578 \pm 6,581$ & $153,186 \pm 4,649$ \\
240,000 & $217,266 \pm 10,171$ & $192,732 \pm 4,691$ \\
315,000 & $268,911 \pm 10,916$ & $238,584 \pm 7,172$ \\
390,000 & $328,028 \pm 13,166$ & $261,530 \pm 7,688$ \\
\hline
\end{tabular}

${ }^{\text {a }}$ Data summarized across all herbicide programs and soybean row spacings.

${ }^{\mathrm{b}}$ Data are means \pm standard errors.

${ }^{\mathrm{c}}$ No significant interaction was present between row spacings.

therefore, late-season visible waterhemp control, density, and soybean yield were separated by year (Table 5). Individual treatment differences were separated using Fisher's protected LSD at $\mathrm{P} \leq 0.05$.

\section{Results and Discussion}

Herbicide Programs. In both years, the PRE $\mathrm{fb}$ POST w/RES program provided greater visible waterhemp control and in 2012 provided greater density reduction than the two-pass POST program (Table 5). In 2012, late-season waterhemp density was reduced from 397 to 5 plants $9 \mathrm{~m}^{-2}$, or by 99\%, with the PRE fb POST w/RES program and by $72 \%$ with the two-pass POST program compared to the nontreated control. Legleiter et al. (2009) reported greater than 97\% GR waterhemp density reductions with PRE $\mathrm{fb}$ POST programs compared to less than $40 \%$ waterhemp density reduction with POST-only programs. In 2013, no density differences were observed between the PRE fb POST w/RES and the two-pass POST program. This was likely due to the later soybean planting date induced by above-average spring rainfall (Table 2) that resulted in lower waterhemp densities. In 2012, there were differences in soybean yield as a result of herbicide programs, but not in 2013. In 2012, the PRE fb POST w/RES program resulted in an average soybean yield of $1,720 \mathrm{~kg}$ $\mathrm{ha}^{-1}$ compared to the two-pass POST program at $1,560 \mathrm{~kg} \mathrm{ha}^{-1}$. The use of PRE herbicides in soybean often results in increased yields in environments with high waterhemp densities, because waterhemp emergence can usually be delayed through the V4 to V5 critical weed-free stage
(Legleiter et al. 2009; Steckel and Sprague 2004). It is also important to note that in both years, both herbicide treatments resulted in greater yields than the nontreated control. Visible crop injury did not exceed $2 \%$ at any time interval after application in either year.

Row Spacing. Visible waterhemp control was greater in $19-$ and $38-\mathrm{cm}$ rows than $76-\mathrm{cm}$ rows in both years (Table 5). In 2013, $98 \%$ or greater visible waterhemp control was observed for all soybean row spacings. Additionally, in both years, waterhemp density was lower in 19- and 38-cm compared to $76-\mathrm{cm}$ row spacings. Waterhemp density was reduced by 71 to $75 \%$ in $38-\mathrm{cm}$ rows and by 57 to $93 \%$ in $19-\mathrm{cm}$ rows compared to $76-$ $\mathrm{cm}$ row spacings. Rich and Renner (2007) observed similar effects with eastern black nightshade (Solanum ptycanthum Dunal), where late-season densities were 1 plant $\mathrm{m}^{-2}$ in $19-\mathrm{cm}$ rows and 12 plants $\mathrm{m}^{-2}$ in 76-cm rows. Harder et al. (2007) also reported that weed density 3, 4, and 5 wk after herbicide treatment was reduced in $38-\mathrm{cm}$ compared to $76-\mathrm{cm}$ rows. In 2012, the PRE fb POST w/RES program provided at least $95 \%$ control of waterhemp for all row spacings evaluated, whereas the two-pass POST program provided $95 \%$ control of waterhemp in 19- and 38-cm row spacings, but only $85 \%$ waterhemp control in $76-\mathrm{cm}$ row spacing (data not shown). In 2012, the PRE fb POST w/ RES program also provided greater than 98\% waterhemp density reduction across all row spacings, and the two-pass POST program provided $87 \%, 80 \%$, and $50 \%$ waterhemp density reduction in 19-, 38-, and 76-cm rows, respectively (data not shown). However in 2013, all herbicide program and row spacing combinations resulted in greater than $97 \%$ visible waterhemp control and greater than $98 \%$ density reduction (data not shown). Although 19-cm soybean row spacings provided better waterhemp control than $76-\mathrm{cm}$ row spacings, they yielded lower than $38-$ and $76-\mathrm{cm}$ rows in 2012. This yield reduction might be due to inconsistent seed placement provided by the grain drill. Bracy and Parish (2001) reported that grain drills can provide poor seeding precision due to multiple seed drops and large skips between seed drops. In 2013, no yield differences were observed between soybean row spacings, but there was a significant herbicide program by row spacing interaction. Both the PRE $\mathrm{fb}$ POST w/RES and 
Table 5. Late-season visible waterhemp control and density (taken at R4 soybean growth stage), and soybean yield as affected by herbicide program, row spacing, and seeding rate.

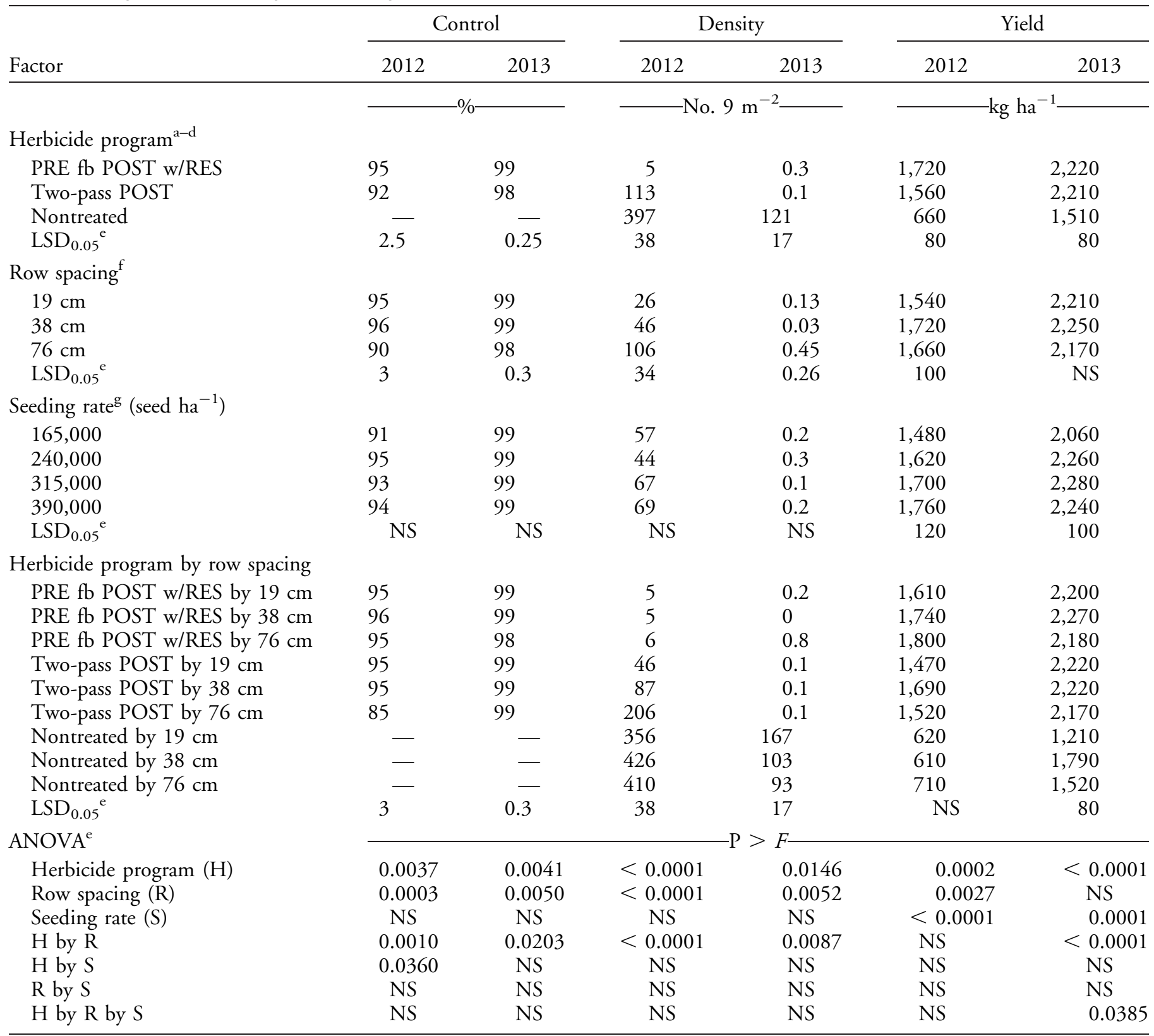

${ }^{\text {a }}$ All POST treatment included ammonium sulfate at $2.9 \mathrm{~kg}$ ai ha ${ }^{-1}$.

b Abbreviations: fb, followed by; w/RES, with residual.

${ }^{c}$ Application timing: PRE, at planting; early POST, 10-cm waterhemp; late POST, 10-cm waterhemp regrowth.

${ }^{\mathrm{d}}$ Data combined across all row spacings and seeding rates.

e NS, not significant at the $\alpha=0.05$ level.

${ }^{\mathrm{f}}$ Data combined across all row spacings and plots with herbicide applications.

g Data combined across all seeding rates and plots with herbicide applications.

the two-pass POST treatments in $76-\mathrm{cm}$ rows yielded less than the 19- and 38-cm row spacings. The response of soybean to row spacing has been inconsistent within the literature. Taylor (1980) reported that in years where rainfall was below average there were no yield differences between 25-, $50-, 75-$, and $100-\mathrm{cm}$ soybean row spacings. However, when rainfall was ample throughout the 
growing season, $25-\mathrm{cm}$ rows yielded higher than $100-\mathrm{cm}$ rows (Taylor 1980). Buehring et al. (2002) observed a similar response and suggested that interactions between row spacing and environment might cause variability in yield response to row spacing.

Seeding Rate. No differences in visible waterhemp control or density reduction were observed in response to soybean seeding rate (Table 5). Arce et al. (2009) reported no differences in weed density at two of three sites in response to soybean seeding rates ranging from 240,000 to 420,000 seeds $\mathrm{ha}^{-\mathrm{P}}$. Harder et al. (2007) observed no differences in weed control among four soybean plant populations following an effective POST application. In 2012, soybean yield was greatest in response to the two highest seeding rates of 315,000 and 390,000 seeds $\mathrm{ha}^{-1}$. In terms of yield, the seeding rates of 240,000 and 315,000 seeds $\mathrm{ha}^{-1}$ were not different but were higher than that provided by the 165,000 seeds ha ${ }^{-1}$ seeding rate. In 2013, the three highest seeding rates yielded 180 to $216 \mathrm{~kg} \mathrm{ha}^{-1}$ higher than the 165,000 seeds $\mathrm{ha}^{-1}$ seeding rate. Pedersen (2008) recommended a final plant population of 247,000 plants $\mathrm{ha}^{-1}$ in order to maximize the yield per plant while maintaining overall yield levels.

In summary, the results of this research indicate that the highest levels of waterhemp control and density reduction can be obtained in glufosinateresistant soybean with PRE fb POST w/RES herbicide programs and soybean row spacings of $38 \mathrm{~cm}$ or less. Craigmyle et al. (2013) also observed optimum control of multiple-resistant waterhemp with herbicide programs that included a PRE residual herbicide in glufosinate and 2,4-D soybean, but did not investigate the effect of soybean row spacing. Additionally, this research indicates that in fields with high waterhemp densities, PRE fb POST w/RES programs are more likely to provide higher soybean yields than two-pass POST programs. Legleiter et al. (2009) also observed that PRE herbicide applications resulted in the greatest GR waterhemp control and density reduction, and provided the highest soybean yield. Although two-pass POST programs of glufosinate are more likely to provide control of waterhemp in fields with low densities compared to heavily infested fields, adding residual herbicides to the overall weed management program allows for longer periods of control under a broad range of environmental conditions that POST programs alone cannot provide. Based on the results of this research and previous research, soybean seeding rates of 240,000 to 315,000 seeds $\mathrm{ha}^{-1}$ or greater will result in optimum soybean yield (Arce et al. 2009; Pedersen 2008). However, increasing the soybean seeding rate will likely have only minimal impacts on waterhemp control, especially in fields where an effective PRE or POST herbicide application has been made. Glufosinate remains an effective herbicide that can be utilized to manage GR- and multiple-resistant weed species such as waterhemp in glufosinate-resistant soybean. As GR weed species become more prevalent in soybean production systems throughout the United States, the integration of cultural practices such as narrow row spacings and optimum soybean plant populations with herbicide programs that include multiple, effective herbicide modes of action will be critical to the success of GR weed management.

\section{Literature Cited}

Anderson WP, (1996) Weed Science Principles and Applications. 3rd edn. St. Paul, MN: West Publishing Company. 388 $\mathrm{p}$

Arce GD, Pedersen P, Hartzler RG (2009) Soybean seeding rate effects on weed management. Weed Technol 23:17-22

Bernards ML, Crespo RJ, Kruger GR, Gaussoin R, Tranel PJ (2012) A waterhemp (Amaranthus tuberculatus) population resistant to 2,4-D. Weed Technol 60:379-384

Bracy BP, Parish RL (2001) A comparison of seeding uniformity of agronomic and vegetable seeders. Hort Technology 11:184186

Bradley KW (2006) A review of the effects of row spacing on weed management in corn and soybean. Crop Management DOI: 10.1094/CM-2006-0227-02-RV

Bradley KW (2013) Herbicide-resistance in the Midwest: current status and impacts. Weed Sci Soc Am Abstr 53:271.[Abstract]

Bradley KW, Legleiter T, Hunter L, Nichols C, Foresman C (2007) The status of glyphosate-resistant waterhemp in Missouri. Page 192 in Proceedings of the North Central Weed Science Society. Champaign, IL: North Central Weed Science Society [Abstract]

Buehring NW, Shaw DR, Nice GRW (2002) Sicklepod (Senna obtusifolia) control and soybean (Glycine max) response to soybean row spacing and population in three weed management systems. Weed Technol 16:131-141

Burnside OC (1979) Soybean (Glycine max) growth as affected by weed removal, cultivar, and row spacing. Weed Sci 27:562565

Burnside OC, Colville WL (1964) Soybean and weed yields as affected by irrigation, row spacing, tillage, and amiben. Weeds 12:109-112 
Craigmyle BD, Ellis JM, Bradley KW (2013) Influence of herbicide programs on weed management in soybean with resistance to glufosinate and 2,4-D. Weed Technol 27:78-84

Culpepper AS, York AC, Batts RB, Jennings KM (2000) Weed management in glufosinate and glyphosate-resistant soybean (Glycine max). Weed Technol 14:77-88

Dalley CD, Renner KA, Kells JJ (2004) Effect of glyphosate application timing and row spacing on weed growth in corn (Zea mays) and soybean (Glycine max). Weed Technol 18:177182

Grichar WJ, Bessler BA, Brewer KD (2004) Effect of row spacing and herbicide dose on weed control and grain sorghum yield. Crop Prot 23:263-267

Hager A, Wax L, Simmons W, Sprague C (2000) Waterhemp Management in Illinois Agronomic Crops. 2000 Illinois Agricultural Pest Management Handbook. Champaign, IL: University of Illinois Extension. 294 p

Harder DB, Renner KA, Sprague CL (2007) Effect of soybean row width and population on weeds, crop yield, and economic return. Weed Technol 21:744-752

Heap I (2014) The International Survey of Herbicide Resistant Weeds. http://www.weedscience.org/summary/home.aspx. Accessed March 21, 2014

Knezevic SZ, Evans SP, Mainz M (2003) Row spacing influences the critical timing for weed removal in soybean (Glycine max). Weed Technol 17:666-673

Krausz RF, Kapusta G, Matthews JL (1993) Soybean (Glycine max) tolerance to 2,4-D ester applied preplant. Weed Technol 7:906-910

Legere A, Schreiber MM (1989) Competition and canopy architecture as affected by soybean (Glycine max) row width and density of redroot pigweed (Amaranthus retroflexus). Weed Sci 37:84-92

Legleiter TR, Bradley KW (2008) Glyphosate and multiple herbicide resistance in common waterhemp (Amaranthus rudis) populations from Missouri. Weed Sci 56:582-587

Legleiter TR, Bradley KW, Massey RE (2009) Glyphosateresistant waterhemp (Amaranthus rudis) control and economic returns with herbicide programs in soybean. Weed Technol 23:54-61

Mulugeta D, Boerboom CM (2000) Critical time of weed removal in glyphosate-resistant Glycine max. Weed Sci 48:3542

Nelson KA, Renner KA (1998) Weed control in wide- and narrow-row soybean (Glycine max) with imazamox, imazethapyr, and CGA-277476 plus quizalofop. Weed Technol 12:137-144

Norsworthy JK, Oliver LR (2001) Effect of seeding rate of drilled glyphosate-resistant soybean (Glycine max) on seed yield and gross profit margin. Weed Technol 15:284-292

Norsworthy JK, Oliver LR (2002) Hemp sesbania interference in drill-seeded glyphosate-resistant soybean. Weed Sci 50:34-41

Norsworthy JK, Ward SM, Shaw DR, Llewellyn RS, Nichols RL, Webster TM, Bradley KW, Frisvold G, Powles SB, Burgos NR, Witt WW, Barrett M (2012) Reducing the risks of herbicide resistance: best management practices and recommendations. Weed Sci 2012 Special Issue:31-62

O'Donovan JT, Harker KN, Clayton GW, Newman JC, Robinson D, Hall LM (2001) Barley seeding rate influence the effects of variable herbicide rates on wild oat. Weed Sci 49:746-754

Pedersen P (2008) Optimum Plant Population in Iowa. http:// extension.agron.iastate.edu/soybean/documents/Optimum PlantPop.pdf. Accessed November 15, 2013

Pedersen P, Lauer JG (2003) Corn and soybean response to rotation sequence, row spacing, and tillage system. Agron J 95:965-971

Powles SB (2008) Evolved glyphosate-resistant weeds around the world: lessons to be learnt. Pest Manag Sci 64:360-365

Puricelli EC, Faccini DE, Orioli GA, Sabbatini MR (2003) Spurred anoda (Anoda cristata) competition in narrow- and wide-row soybean (Glycine max). Weed Technol 17:446-451

Rich AM, Renner KA (2007) Row spacing and seeding rate effects on eastern black nightshade (Solanum ptycanthum) and soybean. Weed Technol 21:124-130

Rosenbaum KK, Bradley KW (2013) A survey of glyphosateresistant waterhemp in Missouri soybean fields and prediction of glyphosate resistance in future waterhemp populations based on in-field observations and management practices. Weed Technol 27:656-663

Schultz JL, Chatham LA, Riggins CW, Tranel PJ, Bradley KW (2015) Distribution of herbicide resistance and molecular mechanisms conferring resistance in Missouri waterhemp (Amaranthus rudis Sauer) populations. Weed Sci 63:336-345

Shoup DE, Al-Khatib K, Peterson DE (2003) Common waterhemp (Amaranthus rudis) resistance to protoporphyrinogen oxidase-inhibiting herbicides. Weed Sci 51:145-150.

Spaunhorst DJ, Seifert-Higgins S, Bradley KW (2014) Glyphosate-resistant giant ragweed (Ambrosia trifida) and waterhemp (Amaranthus rudis) management in dicamba-resistant soybean (Glycine max). Weed Technol 28:131-141

Steckel LE, Sprague CL (2004) Late-season common waterhemp (Amaranthus rudis) interference in narrow- and wide-row soybean. Weed Technol 18:947-952

Taylor HM (1980) Soybean growth and yield as affected by row spacing and by seasonal water supply. Agron J 72:543-547

Waggoner BS, Bradley KW (2011) A survey of weed incidence and severity in response to management practices in Missouri soybean production fields. Page 80 in Proceedings of the North Central Weed Science Society. Champaign, IL: North Central Weed Science Society [Abstract]

Yelverton FH, Coble HD (1991) Narrow row spacing and canopy formation reduces weed resurgence in soybeans (Glycine max). Weed Technol 5:169-174

Young BG (2006) Changes in herbicide use patterns and production practices resulting from glyphosate resistant crops. Weed Technol 20:301-307

Received June 28, 2014, and approved November 7, 2014. 